Article

\title{
Enzyme-like mechanism of selective toluene oxidation to benzaldehyde over organophosphoric acid-bonded nano-oxides
}

\author{
Changshun Deng, Yun Cui, Junchao Chen, Teng Chen, Xuefeng Guo, Weijie Ji, Luming Peng, \\ Weiping Ding * \\ Key Laboratory of Mesoscopic Chemistry, School of Chemistry and Chemical Engineering, Nanjing University, Nanjing 210023, Jiangsu, China
}

\section{A R T I C L E I N F O}

\section{Article history:}

Received 19 November 2020

Accepted 11 January 2021

Available online 5 May 2021

\section{Keywords:}

Selective oxidation

Toluene

Benzaldehyde

Hexadecylphosphate acid

Enzyme-like

Mechanism

\begin{abstract}
A B S T R A C T
The completely selective oxidation of toluene to benzaldehyde with dioxygen, without the need to use $\mathrm{H}_{2} \mathrm{O}_{2}$, halogens, or any radical initiators, is a reaction long desired but never previously successful. Here, we demonstrate the enzyme-like mechanism of the reaction over hexadecylphosphate acid (HDPA)-bonded nano-oxides, which appear to interact with toluene through specific recognition. The active sites of the catalyst are related to the ability of HDPA to change its bonding to the oxides between monodentate and bidentate during the reaction cycle. This greatly enhances the mobility of the crystal oxygen or the reactivity of the catalyst, specifically in toluene transformations. The catalytic cycle of the catalyst is similar to that of methane monooxygenase. In the presence of catalyst and through $\mathrm{O}_{2}$ oxidation, the conversion of toluene to benzaldehyde is initiated at $70{ }^{\circ} \mathrm{C}$. We envision that this novel mechanism reveals alternatives for an attractive route to design high-performance catalysts with bioinspired structures.
\end{abstract}

(C) 2021, Dalian Institute of Chemical Physics, Chinese Academy of Sciences. Published by Elsevier B.V. All rights reserved.

\section{Introduction}

Selective oxidation of alkanes with molecular oxygen generally has the lowest selectivity compared to other catalytic reactions, and significant quantities of $\mathrm{CO}_{x}$ and water are often obtained apart from the desired partial oxidation products. This causes a need for complex and costly separations that, in turn, result in processes with unusually high capital intensity [1]. Therefore, minimizing or impeding the formation of undesired products has become the primary aim [2-8], however, the arduous challenge is still not shaken. Benzaldehyde is an extremely vital value-added chemical which is extensively used in the synthesis of organic compounds in several industries, including the perfumery, pharmaceutical, and agricultural industries $[3,5,9]$. Out of the several possible selective hydrocarbon oxidation reactions, the catalytic oxidation of toluene with dioxygen to produce benzaldehyde should be the optimum method for the preparation of benzaldehyde. However, this has never been successful, owing to the non-catalyzed autoxidation reactivity of benzaldehyde under aerobic conditions, which is over four orders of magnitude larger than that of toluene $[5,10]$. Hutchings et al. $[6,11,12]$ found that the oxidation of toluene with bimetallic PdAu showed an excellent performance under relatively mild conditions $\left(1 \mathrm{MPa} \mathrm{O}_{2}\right.$ and $160^{\circ} \mathrm{C}$ ), and the main product was benzyl benzoate. Generally, the mild conversion of toluene to benzaldehyde is still challenging [13].

By contrast, natural enzymes, known for their excellent efficacious integration of molecular recognition with catalysis in one functional assembly, possess excellent rate constants and selectivities superior to that achieved through corresponding

\footnotetext{
* Corresponding author. Tel: +86-25-89685077; Fax: +86-25-89687761; E-mail: dingwp@nju.edu.cn

The work was supported by the National Science Foundation of China $(21932004,91745108)$ and the National Key R\&D Program of China (2017YFB0702800).

DOI: 10.1016/S1872-2067(20)63758-5 | http://www.sciencedirect.com/journal/chinese-journal-of-catalysis | Chin. J. Catal., Vol. 42, No. 9, September 2021
} 


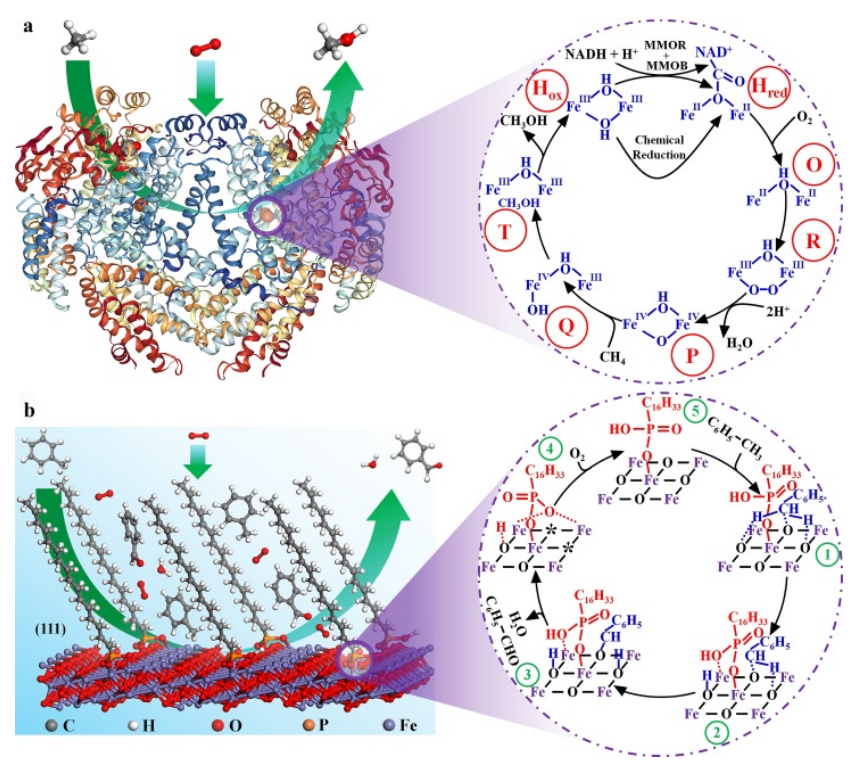

Fig. 1. Schematic of methane monooxygenase and $\mathrm{HDPA}-\mathrm{Fe}_{2} \mathrm{O}_{3}$. (a) Structure of sMMO hydroxylase and the reaction cycle for the transformation of methane to methanol over methane monooxygenase summarized from previous investigations. (b) $\mathrm{HDPA}-\mathrm{Fe}_{2} \mathrm{O}_{3}$ and the possible catalytic cycle of the reaction for the oxidation of toluene presented in this work.

bimolecular reactions under mild conditions. This is owing to the stabilization of the transition state through the formation of enzyme-substrate complexes [14,15]. Many studies have been devoted to explaining the structure and function of enzymes. It is now generally believed that many enzymes catalyze reactions through the complex integration of hydrogen bonding, electrostatic, covalent, and directional interactions [16,17]. As one of the most typical enzymatic catalysts, methane monooxygenase can activate molecular oxygen and $\mathrm{CH}_{4}$ simultaneously by insertion of a dioxygen oxygen atom into the $\mathrm{C}-\mathrm{H}$ bond under very mild conditions [18-21], as summarized in Fig. 1(a). First, $\mathrm{O}_{2}$ is activated at the diiron(II) center of MMOHred ( $\left.\mathrm{H}_{\text {red }}\right)$ to form $\mathrm{O}, \mathrm{P}$, and $\mathrm{Q}$ (peroxodiiron(III)) intermediates successively. During the transformation of $\mathrm{P}$ to $\mathrm{Q}, \mathrm{O}-\mathrm{O}$ bond cleavage occurs. Then, $\mathrm{CH}_{4}$ reacts with these $\mathrm{Q}$ intermediates through a rebound mechanism of methyl free radicals or a coordinated oxygen insertion mechanism accompanying the successive formation of $\mathrm{R}$ and $\mathrm{T}$ intermediates. Finally, $\mathrm{CH}_{3} \mathrm{OH}$ is released and $\mathrm{MMOH}$ returns to the oxidized state $\left(\mathrm{H}_{\mathrm{ox}}\right)$ [21-26].
In our work, we have established a toluene/water Pickering-like emulsion catalytic system with the amphiphilic nanoparticle catalyst (HDPA-bonded nano-iron-based oxides) located at the interface, being highly active for the conversion of toluene to benzaldehyde. A space-time yield for benzaldehyde larger than $2 \mathrm{~g} \cdot \mathrm{g}^{-1} \cdot \mathrm{h}^{-1}$ is achieved by $\mathrm{O}_{2}$ oxidation under mild conditions, without the use of $\mathrm{H}_{2} \mathrm{O}_{2}$, halogens, or any radical initiators [2,7]. The typical catalytic results of some of the reported catalysts are summarized in Table 1.

The catalytic mechanism, including the exact role of HDPA, however, has only been clarified in this study. We have established that the catalysts for the toluene reaction, typically HDPA-FeMO ${ }_{x} / \gamma-\mathrm{Al}_{2} \mathrm{O}_{3}$ (M: V, Mo, etc.), are in fact analogous to methane monooxygenase, though with a much simpler structure. The catalysts can convert toluene exclusively to benzaldehyde through $\mathrm{O}_{2}$ oxidation in a traditional fixed-bed reactor under very mild conditions (70-160 ${ }^{\circ} \mathrm{C}$, ambient pressure), with an apparent activation energy of less than $50 \mathrm{~kJ} / \mathrm{mol}$. The active centers of the catalysts appear to be related to HDPA bonding in the monodentate state to the oxide surface and changes between the unbonding and bonding states of phosphorous hydroxyl on the surface, corresponding to the oxidized or reduced state of the catalyst during the toluene reaction. Through the circular change in the HDPA bonding between monodentate and bidentate, the mobility of the crystal oxygen or the reactivity of the iron-based mixed oxides seems greatly enhanced for the specific conversion of toluene to benzaldehyde. The catalytic cycle over the catalyst is in fact analogous to that of the methane reaction over methane monooxygenase, as summarized in Fig. 1(b). The newly revealed mechanism introduces an attractive example for the design of high-performance catalysts for the selective oxidation of organic molecules.

\section{Experimental}

\subsection{Catalyst preparation}

$\gamma-\mathrm{Al}_{2} \mathrm{O}_{3}$ nanorods were prepared using a similar method as that reported in our previous studies $[7,27]$. The main external surface of the catalyst was the $\{111\}$ surface, although the crystal facet dependence of the catalyst was not evident at that time. $\mathrm{Fe}\left(\mathrm{NO}_{3}\right)_{3} \cdot 9 \mathrm{H}_{2} \mathrm{O}$ was selected as the precursor to prepare $\mathrm{Fe}_{2} \mathrm{O}_{3} / \gamma-\mathrm{Al}_{2} \mathrm{O}_{3}$ by an incipient wet impregnation method. The

\section{Table 1}

Catalytic performances of reported catalysts in the $\mathrm{O}_{2}$ oxidation of toluene to benzaldehyde.

\begin{tabular}{|c|c|c|c|c|c|c|c|c|c|c|}
\hline Entry a & Cat. & Oxidant & Pressure (MPa) & Temp. $\left({ }^{\circ} \mathrm{C}\right)$ & $\mathrm{pH}$ & Time (h) & Conv. (\%) & Sel. (\%) & $\mathrm{STY}^{\mathrm{c}}$ & Ref. \\
\hline 1 & $\mathrm{Fe}_{3} \mathrm{O}_{4}$ & $\mathrm{O}_{2}$ & 3 & 180 & 2.5 & 4 & $<1$ & - & - & \multirow{2}{*}{ [2] } \\
\hline 2 & $\mathrm{HDPA}-\mathrm{Fe}_{3} \mathrm{O}_{4}$ & $\mathrm{O}_{2}$ & 3 & 180 & 2.5 & 4 & 64 & $>99$ & 1.6 & \\
\hline 3 & $25 \mathrm{Fe}_{2} \mathrm{O}_{3} / \mathrm{Al}_{2} \mathrm{O}_{3}$ & $\mathrm{O}_{2}$ & 2 & 180 & 2.5 & 4 & $<8$ & 40 & - & \multirow{4}{*}{ [7] } \\
\hline 4 & $\mathrm{HDPA}-25 \mathrm{Fe}_{2} \mathrm{O}_{3} / \mathrm{Al}_{2} \mathrm{O}_{3}$ & $\mathrm{O}_{2}$ & 2 & 180 & 2.5 & 4 & 71 & $>99$ & 2.0 & \\
\hline 5 & $\left(20 \mathrm{Fe}_{2} \mathrm{O}_{3}-5 \mathrm{NiO}\right) / \mathrm{Al}_{2} \mathrm{O}_{3}$ & $\mathrm{O}_{2}$ & 2 & 180 & 2.5 & 4 & $<8$ & 30 & - & \\
\hline 6 & HDPA- $\left(20 \mathrm{Fe}_{2} \mathrm{O}_{3}-5 \mathrm{NiO}\right) / \mathrm{Al}_{2} \mathrm{O}_{3}$ & $\mathrm{O}_{2}$ & 2 & 180 & 2.5 & 4 & 83 & $>99$ & 2.4 & \\
\hline 7 b & $\mathrm{HDPA}-\mathrm{FeVO}_{x} / \gamma-\mathrm{Al}_{2} \mathrm{O}_{3}$ & $\mathrm{O}_{2}$ & 0.1 & 160 & - & $4000^{\mathrm{d}}$ & $\sim 0.8$ & $>99$ & - & This work \\
\hline
\end{tabular}

a Entry 1-6, gas-liquid-solid reaction $\left(\mathrm{O}_{2}+\right.$ toluene + water + catalyst).

$\mathrm{b}$ Fixed bed reactor at ambient pressure.

'Space-time yield in units of $\mathrm{g} \cdot \mathrm{g}^{-1} \cdot \mathrm{h}^{-1}$.

$\mathrm{d}$ Total space velocity $\left(\mathrm{mL} / \mathrm{g} / \mathrm{h}\right.$, toluene $\left.+\mathrm{O}_{2}\right)$. 
$\mathrm{Fe}_{2} \mathrm{O}_{3}$ loading was defined as the weight ratio of $\mathrm{Fe}_{2} \mathrm{O}_{3} /\left(\mathrm{Fe}_{2} \mathrm{O}_{3}+\right.$ $\mathrm{Al}_{2} \mathrm{O}_{3}$ ) and fixed at $25 \mathrm{wt} \%$. The impregnated material was aged at room temperature overnight, then evaporated at $70{ }^{\circ} \mathrm{C}$ for $24 \mathrm{~h}$, and calcined at $450{ }^{\circ} \mathrm{C}$ for $3 \mathrm{~h}$ in air. The sample was denoted as $\mathrm{Fe}_{2} \mathrm{O}_{3} / \gamma-\mathrm{Al}_{2} \mathrm{O}_{3}$.

The preparation procedure for $\mathrm{FeMO}_{x} / \gamma-\mathrm{Al}_{2} \mathrm{O}_{3}$ (M: Mo, V; the ratio of $\mathrm{Fe}_{2} \mathrm{O}_{3}$ to $\mathrm{MO}_{x}=3: 2$ ) was very similar to that of $\mathrm{Fe}_{2} \mathrm{O}_{3} / \gamma-\mathrm{Al}_{2} \mathrm{O}_{3}$, using $\left(\mathrm{NH}_{4}\right)_{2} \mathrm{MoO}_{4} \cdot 4 \mathrm{H}_{2} \mathrm{O}$ or $\mathrm{NH}_{4} \mathrm{VO}_{3}$ (oxalate was added to promote its dissolution) as the mixed precursors, respectively. The $\mathrm{FeMO}_{x}$ loadings were also fixed at $25 \mathrm{wt} \%$ and the defined weight ratio was similar to that of $\mathrm{Fe}_{2} \mathrm{O}_{3} / \gamma-\mathrm{Al}_{2} \mathrm{O}_{3}$. A similar heat treatment to that of $\mathrm{Fe}_{2} \mathrm{O}_{3} / \gamma-\mathrm{Al}_{2} \mathrm{O}_{3}$ was applied. The samples were labeled as $\mathrm{FeM}-$ $\mathrm{oO}_{x} / \gamma-\mathrm{Al}_{2} \mathrm{O}_{3}$ and $\mathrm{FeVO}_{x} / \gamma-\mathrm{Al}_{2} \mathrm{O}_{3}$, respectively.

For the preparation of $\mathrm{HDPA}-\mathrm{Fe}_{2} \mathrm{O}_{3} / \gamma-\mathrm{Al}_{2} \mathrm{O}_{3}$, moderate HDPA was dissolved in glycol under ultrasonic agitation and the corresponding amount of $\mathrm{Fe}_{2} \mathrm{O}_{3} / \gamma-\mathrm{Al}_{2} \mathrm{O}_{3}$ was added under vigorous stirring. Then, the slurry was transferred to a tube furnace and calcined at $160{ }^{\circ} \mathrm{C}$ for $6 \mathrm{~h}$ in flowing air. The catalyst was denoted as $\mathrm{HDPA}-\mathrm{Fe}_{2} \mathrm{O}_{3} / \gamma-\mathrm{Al}_{2} \mathrm{O}_{3}$. HDPA-FeMoO $\mathrm{H}_{x} /$ $\gamma-\mathrm{Al}_{2} \mathrm{O}_{3}$ and HDPA-FeVO $x / \gamma-\mathrm{Al}_{2} \mathrm{O}_{3}$ were prepared in a similar manner. For all the catalysts, the HDPA loading was set to approximately $0.4 \mathrm{HDPA} / \mathrm{nm}^{2}$, by optimizing the experimental conditions (Fig. S1).

\subsection{Catalyst characterization}

The XRD results were obtained using an XRD-6000 X-ray diffractometer (Shimadzu, Japan) with $\mathrm{Cu} K_{\alpha}(0.15418 \mathrm{~nm})$ radiation. It was configured with a $40 \mathrm{kV}$ voltage and $30 \mathrm{~mA}$ current. The FTIR spectra were obtained under vacuum conditions using a NEXUS870 spectrometer. The textural characteristics of some of the samples were obtained by $\mathrm{N}_{2}$ sorption analysis using a Micrometrics ASAP 2020 adsorption apparatus. The IR spectra of pyridine were obtained using a Termo Nicolet Nexus 470 spectrometer configured with an IR cell containing $\mathrm{CaF}_{2}$ windows that can be vacuumed and heated. In the IR cell, a self-supporting disk of the catalyst (approximately $10 \mathrm{mg}$ ) was pretreated under vacuum at $200^{\circ} \mathrm{C}$ for $1 \mathrm{~h}$, then cooled to $50{ }^{\circ} \mathrm{C}$, and a background scan recorded. Subsequently, the disk was saturated with approximately 25 mbar pyridine vapor at $50{ }^{\circ} \mathrm{C}$ for $0.25 \mathrm{~h}$ and evacuated again for $0.5 \mathrm{~h}$ to eliminate any physically adsorbed pyridine before scanning at 50 ${ }^{\circ} \mathrm{C}$. The TEM results were obtained using a JEOL JEM-2100 at a voltage of $200 \mathrm{kV}$. H2-TPR and CO-TPR were conducted using a chemisorption instrument (Tianjin XQ TP-5080). Before the TPR measurement, the sample was pretreated with $\mathrm{O}_{2}$ at 150 ${ }^{\circ} \mathrm{C}$ for $1 \mathrm{~h}$. The TPR signals were recorded from ambient temperature in $5 \mathrm{vol} \% \mathrm{H}_{2} / \mathrm{Ar}$ or $5 \mathrm{vol} \% \mathrm{CO} / \mathrm{Ar}$ using a heating rate of $5{ }^{\circ} \mathrm{C} / \mathrm{min}$. Solid-state NMR spectroscopy was performed on a Bruker advance III 400 with a MAS dual resonance probe of $4.0 \mathrm{~mm}$ and a maximum speed of $15 \mathrm{kHz}$. XPS was performed using a PHI 5000 VersaProbe with an $\mathrm{Al} \mathrm{K \alpha}$ excitation source. Operando FTIR measurements were conducted using a TENSOR 27 spectrometer. The catalyst was evenly pressed into a disk and subsequently placed in a quartz cell. The diameter of the disk was approximately $0.5 \mathrm{in}$. The disk was pretreated at
$130{ }^{\circ} \mathrm{C}$ for $60 \mathrm{~min}$ in flowing $\mathrm{Ar}$ and then cooled to ambient temperature. Subsequently, the sample was exposed to a controlled stream of $1 \mu \mathrm{L} / \mathrm{min}$ toluene vaporized in the line and 20 $\mathrm{mL} / \mathrm{min} \mathrm{O}_{2}$ or $\mathrm{Ar}$.

\subsection{Gas-phase and gas-liquid-solid reaction}

The gas-phase toluene oxidation reaction with dioxygen was performed in a flow fixed-bed microreactor with $1 \mu \mathrm{L} / \mathrm{min}$ of toluene, vaporized in the line, and $20 \mathrm{~mL} / \mathrm{min}$ of $\mathrm{O}_{2}$. The sample $(0.3 \mathrm{~g})$ was padded into a U-type quartz tube with an inside diameter of $4 \mathrm{~mm}$, and pretreated in flowing $\mathrm{O}_{2}$ at $130{ }^{\circ} \mathrm{C}$ for $0.5 \mathrm{~h}$. Then, the reaction properties were measured between 70 and $200{ }^{\circ} \mathrm{C}$ at $10{ }^{\circ} \mathrm{C}$ intervals. The tail gas was tested using an online GC-9860 equipped with a flame ionization detector (SE-54 column) and two thermal conductivity detectors (Paropak Q and 5A molecular sieves columns). The benzyl alcohol oxidation was performed in a similar manner. The liquid oxidation of toluene was conducted in a $40 \mathrm{~mL}$ Teflon autoclave. Toluene $(0.6 \mathrm{~mL})$ and the sample $(0.06 \mathrm{~g})$ were added to $20 \mathrm{~mL}$ of deionized water, and $\mathrm{a}_{2} \mathrm{SO}_{4}$ solution was used to modify the $\mathrm{pH}$ of the system. High purity $\mathrm{O}_{2}(2.0 \mathrm{MPa})$ was added into the autoclave after purging with $\mathrm{O}_{2}$ three times. Subsequently, under continuous stirring, the autoclave was heated to the specified temperatures. Analysis of the reaction was identical to that used for the gas-phase reaction.

\section{Results and discussion}

\subsection{Morphology of the prepared catalysts}

The TEM images reveal that the morphologies of the related samples $\mathrm{HDPA}-\mathrm{FeMO}_{x} / \gamma-\mathrm{Al}_{2} \mathrm{O}_{3}$ (M: V, Mo; the ratio of $\mathrm{Fe}_{2} \mathrm{O}_{3}$ to $\mathrm{MO}_{x}=3: 2$ ) are similar, indicating that the iron-based mixed oxides are highly dispersed on $\gamma-\mathrm{Al}_{2} \mathrm{O}_{3}$. This is reasonable considering the structural similarities between the sesquioxides of iron and aluminum (Figs. 2(a)-(c)). In light of the specific surface area $\left(\sim 180 \mathrm{~m}^{2} / \mathrm{g}\right)$ of $\gamma-\mathrm{Al}_{2} \mathrm{O}_{3}$, the thickness of $\sim 25 \mathrm{wt} \%$ metal oxide can be calculated as $\sim 2-3$ atomic layers. Therefore, the thickness is too thin to be distinguished by general TEM. The XRD patterns of the samples (Fig. S2) indicate good dispersion of the metal oxides on $\gamma-\mathrm{Al}_{2} \mathrm{O}_{3}$, which is consistent with the TEM results. In addition, no new crystalline phases are detected by XRD after HDPA chemical bonding. The textural parameters (Fig. S3 and Table S1) of the samples, calculated from the results of the $\mathrm{N}_{2}$ sorption analysis, are similar to those of the $\gamma-\mathrm{Al}_{2} \mathrm{O}_{3}$ support. The FT-IR spectra (Fig. S4) indicate the presence of HDPA in the samples [28].

\subsection{Arrangement of HDPA on the catalyst}

The bonding of HDPA to the surface of iron oxide causes the phosphorus in HDPA to become more electropositive, as revealed by the XPS results displayed in Fig. 2(d). The binding energy of $\mathrm{P} 2 \mathrm{p}$ appears at $133.7 \mathrm{eV}$ for $\mathrm{HDPA}-\mathrm{Fe}_{2} \mathrm{O}_{3} / \gamma-\mathrm{Al}_{2} \mathrm{O}_{3}$ and $\mathrm{HDPA}-\mathrm{FeVO}_{x} / \gamma-\mathrm{Al}_{2} \mathrm{O}_{3}$, which implies that HDPA is chemically bonded, not physically included, to the catalyst [29]. The 

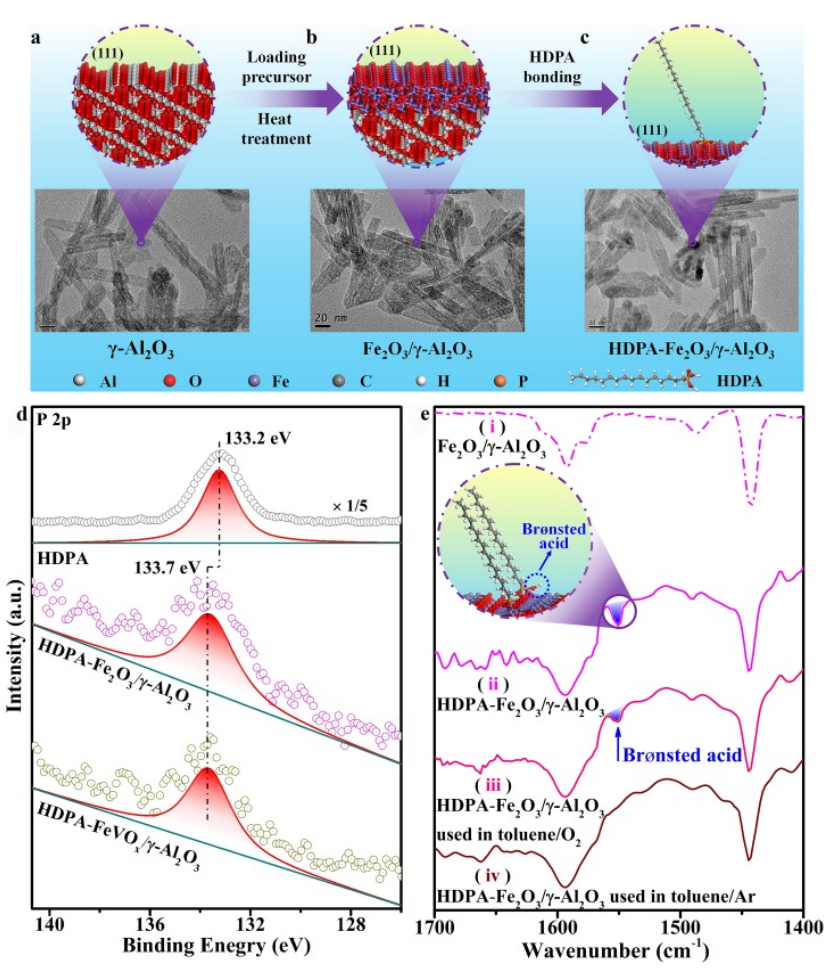

Fig. 2. General synthetic procedure and morphology of the catalysts and the arrangement of HDPA on the catalysts. (a) Nano $\gamma-\mathrm{Al}_{2} \mathrm{O}_{3}$ used as catalytic support and its TEM image, with the $\{111\}$ crystal plane as its main external surface [27]. (b) $25 \mathrm{wt} \% \mathrm{Fe}_{2} \mathrm{O}_{3} / \gamma-\mathrm{Al}_{2} \mathrm{O}_{3}$ prepared by the impregnation and calcination method and its TEM image. (c) HDPA- $\mathrm{Fe}_{2} \mathrm{O}_{3} / \gamma-\mathrm{Al}_{2} \mathrm{O}_{3}$ prepared by bonding $\mathrm{HDPA}$ to 25 wt $\%$ $\mathrm{Fe}_{2} \mathrm{O}_{3} / \gamma-\mathrm{Al}_{2} \mathrm{O}_{3}$ in a density of $0.4 / \mathrm{nm}^{2}$ and its typical TEM image. The TEM observations indicate similar morphologies for the samples. (d) $\mathrm{P}$ $2 p$ binding energy measured by XPS for HDPA, HDPA- $\mathrm{Fe}_{2} \mathrm{O}_{3} / \gamma-\mathrm{Al}_{2} \mathrm{O}_{3}$, and $\mathrm{HDPA}-\mathrm{FeVO}_{x} / \gamma-\mathrm{Al}_{2} \mathrm{O}_{3}$. (e) FTIR result of pyridine adsorbed on $\mathrm{Fe}_{2} \mathrm{O}_{3} / \gamma-\mathrm{Al}_{2} \mathrm{O}_{3} \quad$ (i), fresh HDPA- $\mathrm{Fe}_{2} \mathrm{O}_{3} / \gamma-\mathrm{Al}_{2} \mathrm{O}_{3}$ (ii), and HDPA- $\mathrm{Fe}_{2} \mathrm{O}_{3} / \gamma-\mathrm{Al}_{2} \mathrm{O}_{3}$ after use in toluene $/ \mathrm{O}_{2}$ (iii) or toluene/Ar (iv). The inset shows the proposed Brønsted acid site that originated from monodentate-bonded HDPA on $\mathrm{Fe}_{2} \mathrm{O}_{3} / \gamma-\mathrm{Al}_{2} \mathrm{O}_{3}$.

zeta potentials of the related catalysts are shown in Fig. S5, indicating the positively charged surface properties of the catalysts. From the FTIR spectra of the catalysts with pyridine adsorption (Fig. 2(e), curves i and ii), a signature peak for the pyridinium ion at $1540 \mathrm{~cm}^{-1}$ is observed after pyridine adsorption on $\mathrm{HDPA}-\mathrm{Fe}_{2} \mathrm{O}_{3} / \gamma-\mathrm{Al}_{2} \mathrm{O}_{3}$, indicating the existence of a Brønsted acid site from the unbonded phosphorus hydroxyl. For pure $\mathrm{Fe}_{2} \mathrm{O}_{3} / \gamma-\mathrm{Al}_{2} \mathrm{O}_{3}$, however, no Brønsted acid sites are detected in the experiment. In general, the bonding of HDPA to the oxides occurs through a condensation reaction between the hydroxyls of $\mathrm{P}-\mathrm{OH}$ and the surface $\mathrm{M}-\mathrm{OH}$ (e.g., $\mathrm{Fe}-\mathrm{OH}$ ) species [30]. The $\mathrm{Fe}-\mathrm{OH}$ groups are commonly not detected by pyridine IR owing to their weak acidity [31], despite the consumption of surface hydroxyl groups during HDPA bonding [32]. Therefore, the introduction of Brønsted acidity implies the retention of $\mathrm{P}-\mathrm{OH}$ groups after HDPA bonds to $\mathrm{FeMO}_{x} / \gamma-\mathrm{Al}_{2} \mathrm{O}_{3}$; i.e., at least a part of the HDPA bonds to the catalyst through one phosphorous hydroxyl, as depicted in the inset of Fig. 2(e). This corresponds with the XPS results.

The ${ }^{31} \mathrm{P}$ NMR spectra display a peak at $\sim 33 \mathrm{ppm}$ for free HDPA and two peaks at $\sim 25$ and $\sim 15$ ppm for HDPA- $\gamma-\mathrm{Al}_{2} \mathrm{O}_{3}$
(Fig. S6). There are no ${ }^{31} \mathrm{P}$ signals detected for HDPA- $\mathrm{Fe}_{2} \mathrm{O}_{3} / \gamma-\mathrm{Al}_{2} \mathrm{O}_{3}$ owing to the influence of paramagnetic iron. Generally, the ${ }^{31} \mathrm{P}$ NMR spectrum of free alkylphosphonic acid shows a peak at 30-35 ppm, and the coordination between phosphonate oxygen and metal oxides is considered to produce a high-field chemical shift (e.g., $10 \mathrm{ppm}$ ) [32,33]. According to the trend of coordination-related high-field chemical shifts and peak assignments reported in previous studies [32,33], monodentate, bidentate, and tridentate phosphonates can be reasonably assigned at $\sim 25, \sim 15$, and $0-5 \mathrm{ppm}$, respectively [31]. Therefore, HDPA is likely to be mainly bonded through bidentate bonding and less significantly through monodentate bonding, which is consistent with the XPS and pyridine IR results. Furthermore, the sharp peak at $\sim 0 \mathrm{ppm}$ is absent in Fig. S6, implying that no ferric phosphate was formed during HDPA adsorption, which corresponds with the XRD results.

Overall, the above characterization results reveal that: (1) the iron-based mixed metal oxides are well dispersed on the $\gamma-\mathrm{Al}_{2} \mathrm{O}_{3}$ nanorods over large surface areas; (2) the bonded HDPA retains its organic functionality and does not restructure $\mathrm{FeMO}_{x} / \gamma-\mathrm{Al}_{2} \mathrm{O}_{3}$; (3) a small part of the bonded HDPA molecules retains free phosphorus hydroxyls.

The FTIR spectra of pyridine adsorbed on $\mathrm{HDPA}-\mathrm{Fe}_{2} \mathrm{O}_{3} / \gamma-\mathrm{Al}_{2} \mathrm{O}_{3}$ after the steady-state reaction on a stream of toluene $/ \mathrm{O}_{2}$ or toluene/Ar, are also depicted in Fig. 2(e) as curves iii and iv, respectively. After the steady-state reaction on a stream of toluene $/ \mathrm{O}_{2}$, the Brønsted acid site offered by one free phosphorous hydroxyl can be detected by pyridine adsorption. However, after the reaction on a stream of toluene/Ar, the Brønsted acid site from the monodentate HDPA cannot be detected, implying that the bonding mode of HDPA changes from monodentate to bidentate. This is most likely due to some surface crystal oxygen species being consumed during the toluene reaction without the presence of gaseous oxygen.

\subsection{Operando FTIR of the toluene reaction}

Operando FTIR measurements of the toluene reaction over the $\mathrm{FeVO}_{x} / \gamma-\mathrm{Al}_{2} \mathrm{O}_{3}$ and $\mathrm{HDPA}-\mathrm{FeVO}_{x} / \gamma-\mathrm{Al}_{2} \mathrm{O}_{3}$ catalysts were performed by increasing the temperature stepwise. The results are summarized and shown in Fig. 3. The background spectra collected at room temperature, using clean samples preconditioned in flowing $\mathrm{Ar}$ at $130{ }^{\circ} \mathrm{C}$ for $1 \mathrm{~h}$, are shown in Fig. S7. With the $\mathrm{FeVO}_{x} / \gamma-\mathrm{Al}_{2} \mathrm{O}_{3}$ catalyst, no changes in the FTIR spectra are detected when performing the reaction on a stream of toluene $/ \mathrm{O}_{2}$ during heating (Figs. 3(a), (d)). With the HDPA-FeVO ${ }_{x} / \gamma-\mathrm{Al}_{2} \mathrm{O}_{3}$ catalyst, however, interesting results are achieved, as shown in Figs. 3(b) and (e). At room temperature, the peaks at 2934 and $2879 \mathrm{~cm}^{-1}$ are ascribed to the asymmetric and symmetric $\mathrm{C}-\mathrm{H}$ stretching vibrations of the methyl group of toluene [34-36]. The three bands between 1946 and $1797 \mathrm{~cm}^{-1}$ refer to frequency doubling peaks, which are characteristics of monosubstituted aromatic rings. The peaks at $1603 \mathrm{~cm}^{-1}$ are ascribed to the symmetric $\mathrm{C}=\mathrm{C}$ stretching vibrations of the benzene ring, those at 1538 and $1494 \mathrm{~cm}^{-1}$ refer to the $\mathrm{C}-\mathrm{C}$ stretching vibrations of the benzene ring [37], those at 1455 and $1384 \mathrm{~cm}^{-1}$ refer to the asymmetric and symmetric 

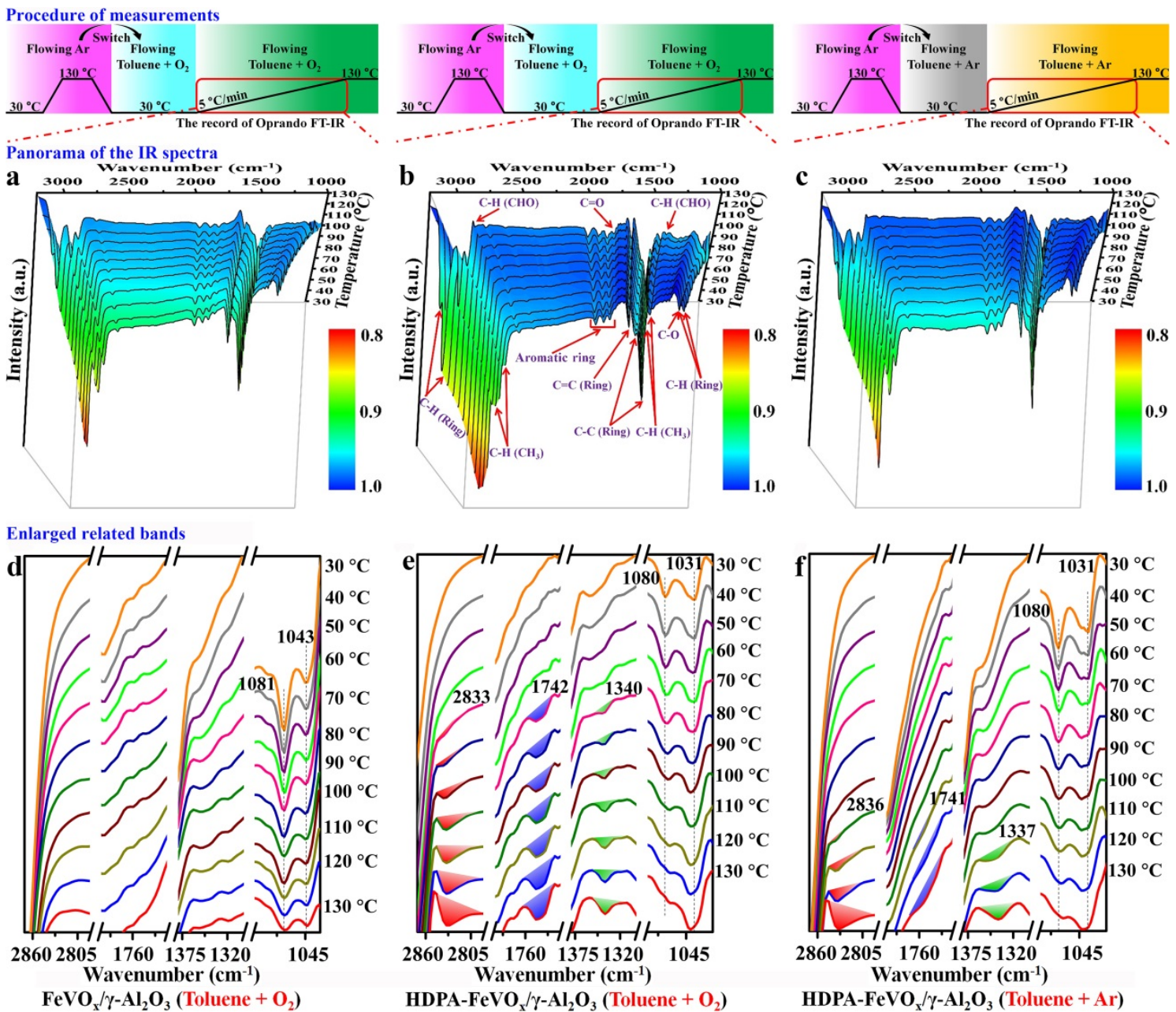

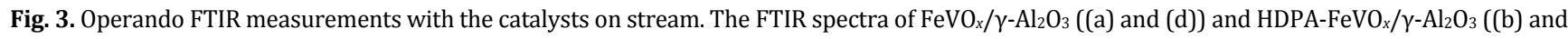
(e)) in flowing toluene and oxygen at different temperatures. (c) and (f) depict the FTIR spectra of $\mathrm{HDPA}-\mathrm{FeVO}_{x} / \gamma-\mathrm{Al}_{2} \mathrm{O}_{3}$ in flowing toluene and argon at different temperatures. (Toluene: $1 \mu \mathrm{L} / \mathrm{min}$, vaporized in the line; $\mathrm{O}_{2}$ or Ar: $20 \mathrm{~mL} / \mathrm{min}$; catalyst of $\sim 0.01 \mathrm{~g}$ pressed into a disk; temp.: $30-130{ }^{\circ} \mathrm{C}$ ).

in-plane $\mathrm{C}-\mathrm{H}$ bending vibrations of methyl [34,38], and the peaks at 1080 and $1031 \mathrm{~cm}^{-1}$ refer to the in-plane $\mathrm{C}-\mathrm{H}$ bending vibrations of the benzene ring [37,38]. Significantly, three new bands at 2833, 1340, and $1742 \mathrm{~cm}^{-1}$, ascribed to the stretching and deformation vibrations of the aldehyde $\mathrm{C}-\mathrm{H}$ bonds and the stretching vibrations of $\mathrm{C}=0$, respectively, emerge at a temperature as low as $70{ }^{\circ} \mathrm{C}$ and become stronger with increasing temperature (Figs. 3(b) and (e)) [39-42]. The results of the operando IR measurements obtained during the toluene reaction are summarized and listed in Table 2. In addition, the bands attributed to either the asymmetric or symmetric stretching vibrations of the carboxylate group $(\sim 1566$ and $\left.1412 \mathrm{~cm}^{-1}\right)$ or adsorbed $\mathrm{CO}_{2}\left(\sim 2360\right.$ and $\left.2340 \mathrm{~cm}^{-1}\right)$ are not observed [34,35,40,43]. These results indicate that HDPA- $\mathrm{FeVO}_{x} / \gamma-\mathrm{Al}_{2} \mathrm{O}_{3}$ can oxidize toluene to benzaldehyde at temperatures as low as $70{ }^{\circ} \mathrm{C}$ without over oxidation, although benzaldehyde in the gas phase can only be detected by GC from $130{ }^{\circ} \mathrm{C}$ owing to its high boiling point of $179^{\circ} \mathrm{C}$ and adsorption by the catalyst.

The FTIR spectra of HDPA-FeVO $x / \gamma-\mathrm{Al}_{2} \mathrm{O}_{3}$ in flowing toluene/Ar were recorded at different temperatures, as shown in Figs. 3(c) and (f). It is clear that the stretching and deformation vibrations of the aldehyde $\mathrm{C}-\mathrm{H}$ bond (2836 and $1337 \mathrm{~cm}^{-1}$ ) and the stretching vibrations of $\mathrm{C}=0\left(1741 \mathrm{~cm}^{-1}\right)$ also appear, suggesting that the lattice oxygen species of HDPA-FeMO $x / \gamma-\mathrm{Al}_{2} \mathrm{O}_{3}$ can participate in the oxidation of toluene to benzaldehyde in the presence of bonded HDPA and absence of gaseous oxygen.

\subsection{Specific interaction of toluene with the catalyst}

The specificity toward toluene oxidation by the HDPA- $\mathrm{Fe}_{2} \mathrm{O}_{3} / \gamma-\mathrm{Al}_{2} \mathrm{O}_{3}$ catalyst was further elucidated by comparing it with the oxidation of benzyl alcohol over the $\mathrm{Fe}_{2} \mathrm{O}_{3} / \gamma-\mathrm{Al}_{2} \mathrm{O}_{3}$ and $\mathrm{HDPA}-\mathrm{Fe}_{2} \mathrm{O}_{3} / \gamma-\mathrm{Al}_{2} \mathrm{O}_{3}$ catalysts. In contrast to the toluene reaction, the $\mathrm{Fe}_{2} \mathrm{O}_{3} / \gamma-\mathrm{Al}_{2} \mathrm{O}_{3}$ catalyst shows much better activity for the benzyl alcohol reaction than the HDPA- $\mathrm{Fe}_{2} \mathrm{O}_{3} / \gamma-\mathrm{Al}_{2} \mathrm{O}_{3}$ catalyst (Fig. 4(a)). Accordingly, the adsorptions of toluene and benzyl alcohol by the two catalysts from a mixed solution of toluene and benzyl alcohol in ethanol are shown in Fig. 4(b), and it is established that, as expected, the $\mathrm{Fe}_{2} \mathrm{O}_{3} / \gamma-\mathrm{Al}_{2} \mathrm{O}_{3}$ catalyst prefers to adsorb benzyl alcohol, while the $\mathrm{HDPA}-\mathrm{Fe}_{2} \mathrm{O}_{3} / \gamma-\mathrm{Al}_{2} \mathrm{O}_{3}$ catalyst tends to preferentially adsorb toluene. The difference is significant. Moreover, the operando IR spectra (Fig. 3) may also suggest the specific 
Table 2

Changes in the IR bands with the catalysts on stream during heating $\left(30-130{ }^{\circ} \mathrm{C}\right)$.

\begin{tabular}{|c|c|c|c|c|c|c|c|}
\hline \multicolumn{2}{|c|}{$\mathrm{FeVO}_{x} / \gamma-\mathrm{Al}_{2} \mathrm{O}_{3}$ (Toluene $+\mathrm{O}_{2}$ ) } & \multicolumn{2}{|c|}{$\mathrm{HDPA} \mathrm{FeVO}_{x} / \gamma-\mathrm{Al}_{2} \mathrm{O}_{3}\left(\right.$ Toluene $+\mathrm{O}_{2}$ ) } & \multicolumn{2}{|c|}{$\mathrm{HDPA}^{-\mathrm{FeVO}_{x}} / \gamma-\mathrm{Al}_{2} \mathrm{O}_{3}$ (Toluene $+\mathrm{Ar}$ ) } & \multirow{2}{*}{ Assignment $^{\mathrm{a}}$} & \multirow{2}{*}{ Ref. } \\
\hline Position & Intensity & Position & Intensity & Position & Intensity & & \\
\hline 2934 & \multirow{13}{*}{ n.c. ${ }^{b}$} & 2934 & \multirow{2}{*}{ weak } & 2933 & \multirow{2}{*}{ weak } & $\nu_{\text {as }}(\mathrm{CH})$ & \multirow{2}{*}[34-36]{} \\
\hline 2879 & & 2879 & & 2877 & & $v_{\mathrm{s}}(\mathrm{CH})$ & \\
\hline - & & 2833 & $\uparrow$ from $70^{\circ} \mathrm{C}$ & 2836 & $\uparrow$ from $100^{\circ} \mathrm{C}$ & $v(\mathrm{CH})$, aldehyde & [39-42] \\
\hline 1948-1799 & & $1946-1797$ & weak & $1945-1800$ & weak & ring, freq. doubling & \\
\hline - & & 1742 & $\uparrow$ from $70^{\circ} \mathrm{C}$ & 1741 & $\uparrow$ from $120^{\circ} \mathrm{C}$ & $v(\mathrm{C}=0)$ & [39-42] \\
\hline 1605 & & 1603 & \multirow{5}{*}{ weak } & 1602 & \multirow{5}{*}{ weak } & $\nu_{\mathrm{s}}(\mathrm{C}=\mathrm{C})$, ring & \multirow{3}{*}[37]{} \\
\hline 1540 & & 1538 & & 1536 & & \multirow{2}{*}{$v(\mathrm{CC})$, ring } & \\
\hline 1495 & & 1494 & & 1496 & & & \\
\hline 1460 & & 1455 & & 1457 & & $\beta_{\text {as }}(\mathrm{CH})$ & \multirow{2}{*}[34,38]{} \\
\hline 1383 & & 1384 & & 1381 & & $\beta_{\mathrm{s}}(\mathrm{CH})$ & \\
\hline - & & 1340 & $\uparrow$ from $70^{\circ} \mathrm{C}$ & 1337 & $\uparrow$ from $110^{\circ} \mathrm{C}$ & $\delta(\mathrm{CH})$, aldehyde & [39-42] \\
\hline 1081 & & 1080 & \multirow{2}{*}{$\begin{array}{c}\text { Interesting } \\
\text { (cf. Fig. 4) }\end{array}$} & 1080 & Interesting & \multirow{2}{*}{$\beta(\mathrm{CH})$, ring } & \multirow{2}{*}[37,38]{} \\
\hline 1043 & & 1031 & & 1031 & (cf. Fig. 4) & & \\
\hline
\end{tabular}

a $\beta_{\text {as }}$ and $\beta_{\mathrm{s}}$ : asymmetric and symmetric in-plane bending vibrations; $\beta$ : in-plane bending vibrations; $v$ : stretching vibrations; $v_{\text {as }}$ and $v_{\mathrm{s}}$ : asymmetric and symmetric stretching vibrations; $\delta$ : deformation vibrations. ${ }^{\text {b }}$ not changed.

recognition of toluene by the $\mathrm{HDPA}-\mathrm{Fe}_{2} \mathrm{O}_{3} / \gamma-\mathrm{Al}_{2} \mathrm{O}_{3}$ catalyst. For the IR cell loaded with $\mathrm{FeVO}_{x} / \gamma-\mathrm{Al}_{2} \mathrm{O}_{3}$ catalyst under flowing $\mathrm{O}_{2}$ containing gaseous toluene, the two peaks corresponding to toluene molecules and related to the in-plane $\mathrm{C}-\mathrm{H}$ bending vibrations of the benzene ring appear at 1081 and $\sim 1043$ $\mathrm{cm}^{-1}$ at a fixed intensity ratio; i.e., $I_{1081} / I_{1043}$ changes only slightly with increasing temperature (Fig. 3(d) and Fig. 4(c)). For toluene adsorption on the HDPA-FeVO ${ }_{x} / \gamma-\mathrm{Al}_{2} \mathrm{O}_{3}$ catalyst, the two peaks slightly deviate to $\sim 1080$ and $1031 \mathrm{~cm}^{-1}$, respectively. However, the intensity ratio, $I_{1080} / I_{1031}$, gradually decreases with increasing temperature (Figs. 3(e), (f), and Fig. $4(c)$ ), regardless of the presence or absence of gaseous oxygen. This phenomenon implies that the micro-environment of HDPA- $\mathrm{FeVO}_{x} / \gamma-\mathrm{Al}_{2} \mathrm{O}_{3}$ already strongly influences the toluene molecules, even at very low temperatures, although $\mathrm{C}-\mathrm{H}$ bond cleavage does not occur. When the temperature increases to $\sim 70{ }^{\circ} \mathrm{C}$, fracturing of the $\mathrm{C}-\mathrm{H}$ bond and formation of a new $\mathrm{C}-\mathrm{O}$ bond is initiated. The catalytic mechanism for toluene oxidation over HDPA-FeVO $\mathrm{F}_{x} / \gamma-\mathrm{Al}_{2} \mathrm{O}_{3}$ is similar to that of methane monooxygenase for methane oxidation, as shown in Fig. 1.

\subsection{Gas-phase toluene reaction in a traditional fixed-bed reactor}

The results of the gas-phase toluene reaction over the catalysts at temperatures ranging between 70 and $200{ }^{\circ} \mathrm{C}$, under ambient pressure, and with molecular oxygen as the oxidant show that all the samples exhibit catalytic activity for toluene conversion, and benzaldehyde is detected in the gas phase at $130{ }^{\circ} \mathrm{C}$, except when using $\mathrm{Fe}_{2} \mathrm{O}_{3} / \gamma-\mathrm{Al}_{2} \mathrm{O}_{3}$ (Fig. S8(a)). During the continuous reaction, all the catalysts with HDPA bonding are selective toward benzaldehyde in the range of temperatures tested, indicating that HDPA bonding on the metal oxides is vital to activate the benzylic $\mathrm{C}-\mathrm{H}$ bond and for the formation of benzaldehyde at low temperatures. Moreover, among the metals, such as $\mathrm{V}$ and Mo, $\mathrm{V}$ doping provides the best promotional effect, possibly owing to the interactions among the components (Fig. S9). At a constant temperature of $160^{\circ} \mathrm{C}$, the
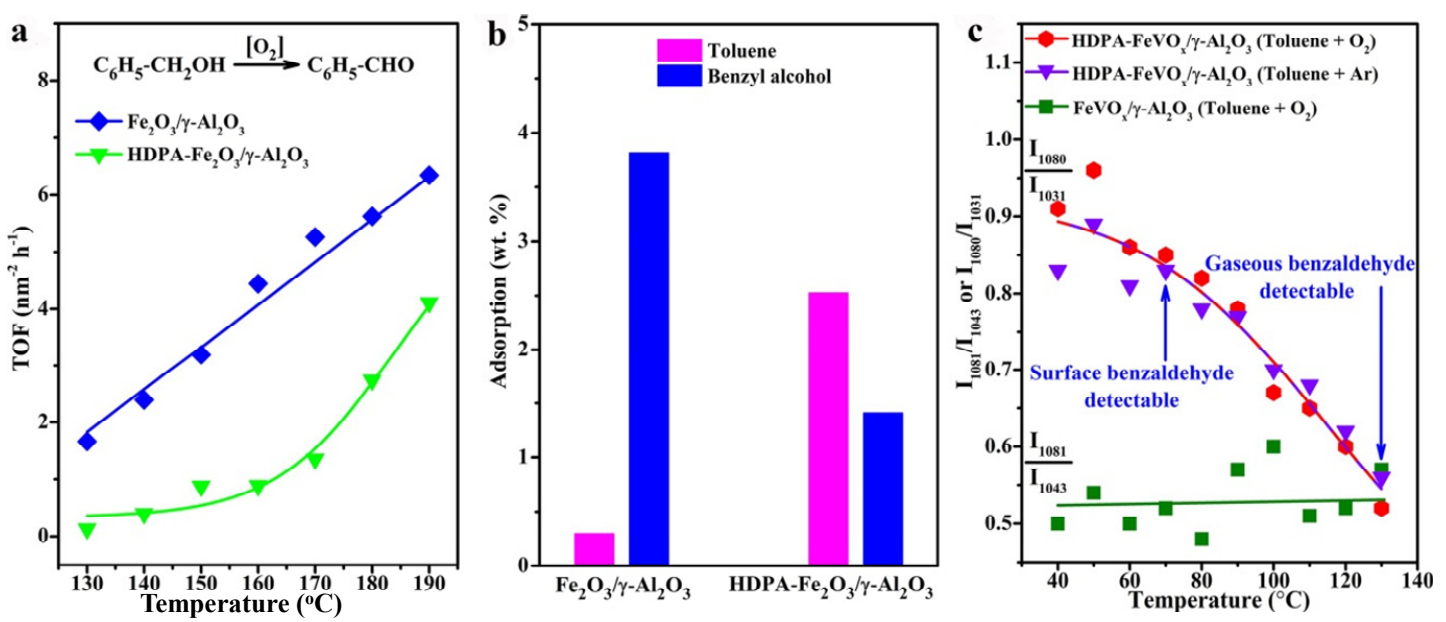

Fig. 4. Specificity of the catalyst toward toluene oxidation. (a) Turnover frequency (TOF) for benzyl alcohol oxidation over $\mathrm{HDPA}^{\mathrm{FeVO}} \mathrm{O}_{x} / \gamma-\mathrm{Al}_{2} \mathrm{O}_{3}$ and $\mathrm{FeVO}_{\mathrm{x}} / \gamma-\mathrm{Al}_{2} \mathrm{O}_{3}$ based on surface area. (Benzyl alcohol: $1 \mu \mathrm{L} / \mathrm{min}$, vaporized in the line; $\mathrm{O}_{2}: 20 \mathrm{~mL} / \mathrm{min}$; cat.: $0.3 \mathrm{~g}$; temp.: $130-190{ }^{\circ} \mathrm{C}$ ). (b) The adsorption of toluene and benzyl alcohol by the two catalysts in a mixed ethanol solution of toluene and benzyl alcohol (cat:: $0.3 \mathrm{~g}$; $30 \mathrm{mg}$ toluene and $30 \mathrm{mg}$ benzyl alcohol in $50 \mathrm{~mL}$ ethanol; temp.: $50^{\circ} \mathrm{C}$ ). (c) The intensity ratio of the two IR peaks related to the in-plane $\mathrm{C}-\mathrm{H}$ bending vibrations of the toluene aromatic ring for toluene adsorption over the catalysts during heating between 40 and $130{ }^{\circ} \mathrm{C}$. 
oxidation of toluene to benzaldehyde over HDPA-FeVO ${ }_{x} / \gamma-\mathrm{Al}_{2} \mathrm{O}_{3}$ appears stable for $50 \mathrm{~h}$ on stream (Fig. S8(b)). The characterization results show that the arrangement of HDPA over $\mathrm{FeVO}_{\mathrm{x}} / \gamma-\mathrm{Al}_{2} \mathrm{O}_{3}$ is similar to that over HDPA- $\mathrm{Fe}_{2} \mathrm{O}_{3} / \gamma-\mathrm{Al}_{2} \mathrm{O}_{3}$ (Figs. S6, S9, and S10). The catalysts maintained exclusive selectivity toward benzaldehyde but exhibited much lower activity than in the gas-liquid-solid reaction (cf. Table 1).

\subsection{Density of the active sites on the catalysts}

Fig. 5(a) shows the $\mathrm{H}_{2}$-TPR results of $\mathrm{Fe}_{2} \mathrm{O}_{3} / \gamma-\mathrm{Al}_{2} \mathrm{O}_{3}$ before and after HDPA bonding. The initial temperature at which HDPA- $\mathrm{Fe}_{2} \mathrm{O}_{3} / \gamma-\mathrm{Al}_{2} \mathrm{O}_{3}$ is reduced by $\mathrm{H}_{2}$ astonishingly decreases to $\sim 50{ }^{\circ} \mathrm{C}$, compared with $\sim 180{ }^{\circ} \mathrm{C}$ for the $\mathrm{Fe}_{2} \mathrm{O}_{3} / \gamma-\mathrm{Al}_{2} \mathrm{O}_{3}$ catalyst. This suggests that HDPA bonding strongly influences the mobility of crystal oxygen or the reducibility of the metal oxides, which accounts for its activity in the oxidation of toluene at temperatures lower than $130{ }^{\circ} \mathrm{C}$. A similar trend is observed in the CO-TPR results, shown in Fig. S11.

After establishing that toluene conversion can occur on the catalyst surface in the absence of gaseous oxygen, the active oxygen species, or the density of the active sites on the HDPA- $\mathrm{Fe}_{2} \mathrm{O}_{3} / \gamma-\mathrm{Al}_{2} \mathrm{O}_{3}$ catalyst could be measured as follows. When the steady-state was achieved for the reaction at $160{ }^{\circ} \mathrm{C}$ over $\mathrm{HDPA}-\mathrm{Fe}_{2} \mathrm{O}_{3} / \gamma-\mathrm{Al}_{2} \mathrm{O}_{3}$ in flowing toluene $/ \mathrm{O}_{2}$, the flowing toluene $/ \mathrm{O}_{2}$ was switched to flowing toluene/Ar, and the outflow curves of benzaldehyde and oxygen were detected by online GC analysis. The results are shown in Fig. 5(b). The concentration of $\mathrm{O}_{2}$ in the gas phase almost instantly decreases to an undetectable level, while that of benzaldehyde slowly decreases to an undetectable level over $\sim 2 \mathrm{~h}$. The color of the catalyst changes from brick red $\left(\mathrm{O}_{2}\right.$ atmosphere) to dull red $\mathrm{Ar}$ atmosphere) due to the removal of active oxygen species by the toluene reaction, similar to the colors of arterial and venous blood. Based on these results, the proportion of active oxygen species stored in the catalyst was calculated to be $\sim 2 \%$ of that of HDPA at $160{ }^{\circ} \mathrm{C}$. This implies that only approximately $2 \%$ monodentate HDPA is present on the HDPA- $\mathrm{Fe}_{2} \mathrm{O}_{3} / \gamma-\mathrm{Al}_{2} \mathrm{O}_{3}$
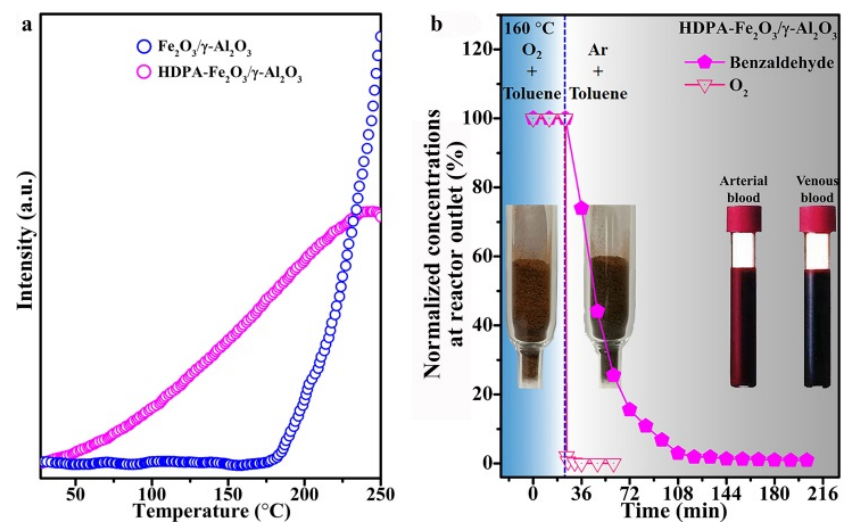

Fig. 5. Redox behavior of the catalysts. (a) $\mathrm{H}_{2}$-TPR results of $\mathrm{Fe}_{2} \mathrm{O}_{3} / \gamma-\mathrm{Al}_{2} \mathrm{O}_{3}$ before and after HDPA bonding; (b) Gas-phase concentrations of benzaldehyde and $\mathrm{O}_{2}$ over $\mathrm{HDPA}-\mathrm{Fe}_{2} \mathrm{O}_{3} / \gamma-\mathrm{Al}_{2} \mathrm{O}_{3}$ during the switch from toluene $+\mathrm{O}_{2}$ to toluene $+\mathrm{Ar}$ (toluene: $1 \mu \mathrm{L} / \mathrm{min}$, vaporized in the line; $\mathrm{O}_{2}$ or Ar: $20 \mathrm{~mL} / \mathrm{min}$; cat.: $1 \mathrm{~g}$; temp.: $160^{\circ} \mathrm{C}$ ). catalyst, which is consistent with the NMR results of HDPA- $\gamma-\mathrm{Al}_{2} \mathrm{O}_{3}$. Increasing the amount of monodentate HDPA on the catalyst could further promote the activity of the catalyst in the reaction. Based on this result, it was established that the optimal $\mathrm{pH}$ value for the gas-liquid-solid reaction (cf., Table 1) is 2.5; i.e., this $\mathrm{pH}$ assists the bonding of a higher concentration of monodentate HDPA to the oxides.

\subsection{Kinetics of the toluene reaction}

Referring to the toluene reaction catalytic cycle shown in Fig. 1(b), the apparent activation energy for benzaldehyde formation over the HDPA-FeVO ${ }_{x} / \gamma-\mathrm{Al}_{2} \mathrm{O}_{3}$ catalyst was found to be $\sim 44.5 \mathrm{~kJ} / \mathrm{mol}$ (Fig. 6(a)). This is much lower than that of the $\mathrm{V}_{2} \mathrm{O}_{5}$-based and $\mathrm{MoO}_{3}$-based traditional catalysts used in the gas-phase selective oxidation of toluene reported in the past, of which the apparent activation energies are commonly larger than $100 \mathrm{~kJ} / \mathrm{mol}$ at higher temperatures $\left(>300^{\circ} \mathrm{C}\right)[44,45]$. The low activation energy suggests that it is feasible for toluene to be converted to benzaldehyde at low temperatures, which may be beneficial from the unique local structure of the active sites which constitute HDPA bonding to the catalyst surface through multiple bonding modes.

The catalytic cycle was further verified by measuring the dependence of the reaction rate on the partial pressure of toluene or oxygen under steady-state conditions (Fig. 6(b)). The benzaldehyde formation rate appears to increase linearly with the toluene partial pressure at a constant $\mathrm{O}_{2}$ partial pressure and the partial order for toluene is close to unity. However, the benzaldehyde formation rate does not rely on the $\mathrm{O}_{2}$ pressure at a constant toluene pressure, and the partial order of $\mathrm{O}_{2}$ approaches zero, implying that a small amount of gaseous oxygen can re-oxidize the catalytic surface very rapidly. The presence of water in the gas phase seems to inhibit the conversion of toluene, which is different from the liquid reaction which contains acid, as shown in Fig. 6(c).

Combining the above results with the typical redox mechanism of the catalyst proposed by Mars and Van Krevelen $[45,46]$, the elementary steps of the reaction shown in Fig. 1(b) were used to depict the kinetic dependences of the benzaldehyde formation rate on toluene, $\mathrm{O}_{2}$, and $\mathrm{H}_{2} \mathrm{O}$ over the $\mathrm{HDPA}-\mathrm{FeMO}_{x} / \gamma-\mathrm{Al}_{2} \mathrm{O}_{3}$ catalyst.

1. Weak associative adsorption of toluene by interaction with lattice oxygen $\left(\mathrm{O}^{*}\right)$

$$
\mathrm{C}_{7} \mathrm{H}_{8}+\mathrm{O}^{*} \stackrel{K_{1}}{\Leftrightarrow} \mathrm{C}_{7} \mathrm{H}_{8} \mathrm{O}^{*}
$$

2. Activation of the benzyl $\mathrm{C}-\mathrm{H}$ bond by extraction of one $\mathrm{H}$ atom from the adsorbed toluene by a neighboring lattice oxygen (slow process)

$$
\mathrm{C}_{7} \mathrm{H}_{8} \mathrm{O}^{*}+\mathrm{O}^{*} \stackrel{k_{2}}{\rightarrow} \mathrm{C}_{7} \mathrm{H}_{7} \mathrm{O}^{*}+\mathrm{OH}^{*}
$$

3. Desorption of benzaldehyde by extraction of the second $\mathrm{H}$ atom from the adsorbed $\mathrm{C}_{7} \mathrm{H}_{7} \mathrm{O}^{*}$ species by another neighboring lattice oxygen and the formation of a reduced $\mathrm{M}$ center $\left(^{*}\right)$ (fast process)

$$
\mathrm{C}_{7} \mathrm{H}_{7} \mathrm{O}^{*}+\mathrm{O}^{*} \stackrel{k_{3}}{\rightarrow} \mathrm{C}_{7} \mathrm{H}_{6} \mathrm{O}+\mathrm{OH}^{*}+*
$$

4. Recombination of the $\mathrm{OH}$ groups to generate $\mathrm{H}_{2} \mathrm{O}$ and a second reduced $\mathrm{M}$ center $\left({ }^{*}\right)$ 

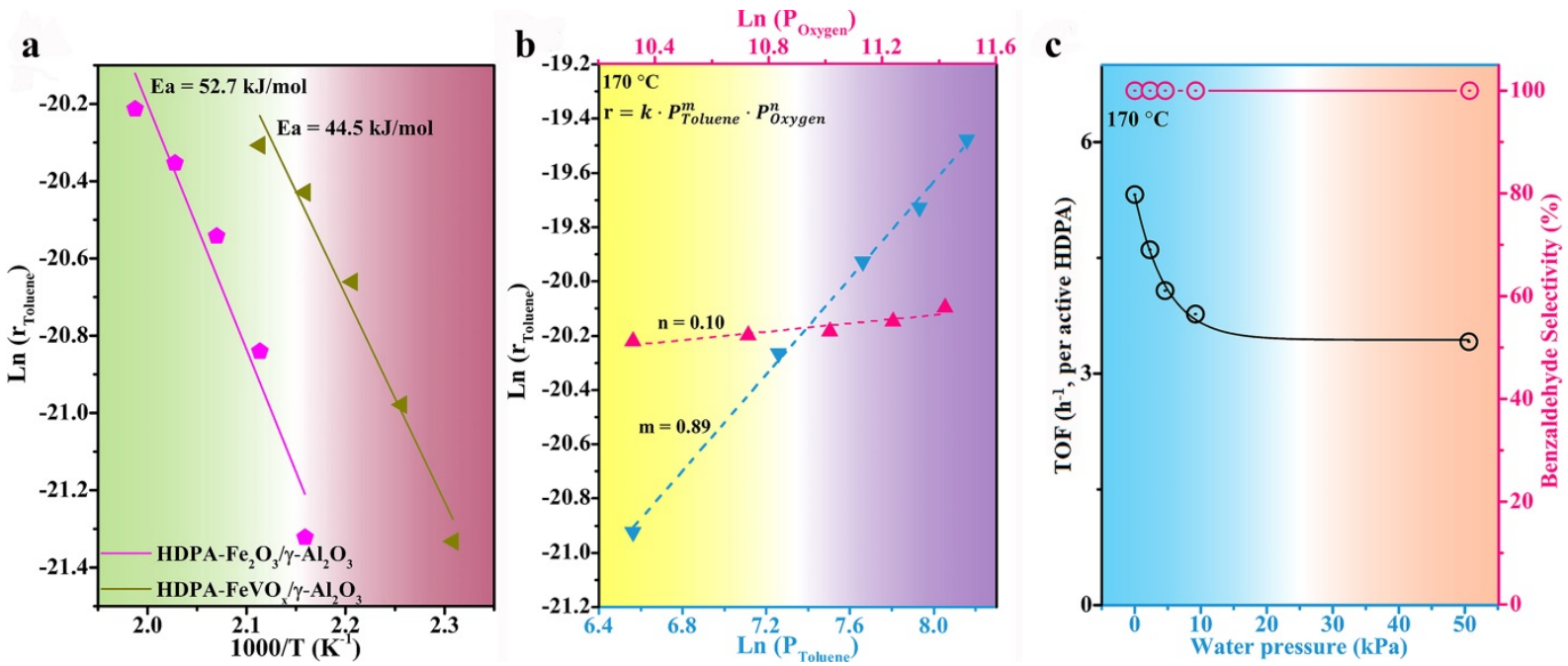

Fig. 6. Kinetic measurements of the toluene oxidation reaction. (a) Arrhenius plots for the gas-phase toluene conversion over $\mathrm{HDPA} \mathrm{Fe} \mathrm{O}_{3} / \gamma$ - $\mathrm{Al}_{2} \mathrm{O}_{3}$ and $\mathrm{HDPA}-\mathrm{FeVO}_{x} / \gamma-\mathrm{Al}_{2} \mathrm{O}_{3}\left(130-170{ }^{\circ} \mathrm{C}\right)$; (b) Dependences of the reaction rate on the partial pressure of toluene or oxygen over $\mathrm{HDPA}^{-\mathrm{FeVO}_{x}} / \gamma-\mathrm{Al}_{2} \mathrm{O}_{3}$ (oxygen: $6-18 \mathrm{~mL} / \mathrm{min}$; toluene: $0.4-2.0 \mu \mathrm{L} / \mathrm{min}$ (liquid); cat.: $0.3 \mathrm{~g}$; temp.: $170{ }^{\circ} \mathrm{C}$. The total flow of the reactant was kept constant at $20 \mathrm{~mL} / \mathrm{min}$ with

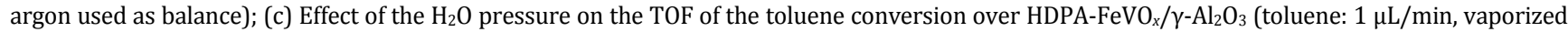
in the line; $\mathrm{O}_{2}: 20 \mathrm{~mL} / \mathrm{min}$; cat:: $0.3 \mathrm{~g}$; temp.: $170^{\circ} \mathrm{C}$ ).

$$
\mathrm{OH}^{*}+\mathrm{OH}^{*} \stackrel{K_{4}}{\Leftrightarrow} \mathrm{H}_{2} \mathrm{O}+\mathrm{O}^{*}+*
$$

5. Reoxidation of the $\mathrm{M}$ centers by dissociative chemisorption of $\mathrm{O}_{2}$ (fast process)

$$
\mathrm{O}_{2}+*+* \stackrel{k_{5}}{\rightarrow} \mathrm{O}^{*}+\mathrm{O}^{*}
$$

where $\mathrm{O}^{*}$ refers to a lattice oxygen neighboring $\mathrm{Fe}$ or $\mathrm{M}$ bonded by HDPA, $\mathrm{OH}^{*}$ refers to a hydroxyl group in $\mathrm{Fe}-\mathrm{OH}$ or $\mathrm{M}-\mathrm{OH}$, $\mathrm{C}_{7} \mathrm{H}_{7} \mathrm{O}^{*}$ refers to an adsorbed benzyl alkoxide species bonded to the crystal lattice oxygen $\left(\mathrm{Fe}-\mathrm{O}-\mathrm{CH}_{2}-\mathrm{C}_{6} \mathrm{H}_{5}\right.$ or $\mathrm{M}-\mathrm{O}-\mathrm{CH}_{2}-\mathrm{C}_{6} \mathrm{H}_{5}$ ), and * refers to a surface oxygen vacancy related to two $\mathrm{Fe}^{2+}$, two $\mathrm{M}(n-1)+$, or one $\mathrm{Fe}^{2+}$ and one $\mathrm{M}(\mathrm{n}-1)+$ cations in the $\mathrm{FeMO}_{x}$ lattice.

The quasi-steady-state assumption of all the reactive intermediates can result in a complicated expression of the reaction rate, and the expression can be simplified via additive assumptions about the reversibility of particular elementary steps. Step one relates to the initial non-dissociative chemisorption of weakly associative toluene. The low activation energy for this procedure and the expected weak binding energy of molecularly adsorbed toluene probably result in quasi-equilibrated sorption steps with an equilibrium constant $K_{1}$. The recombination of the $\mathrm{OH}$ groups should be invertible and nearly quasi-equilibrated with an equilibrium constant $K_{4}$, according to the above water inhibition experiment, which would not be probable in the event of irreversibility of step four. In addition, considering that the valence states of HDPA-FeVO $/ \gamma-\mathrm{Al}_{2} \mathrm{O}_{3}$ are very similar before and after the reaction performed, based on the XPS patterns of $\mathrm{V}, \mathrm{Fe}$, and $\mathrm{P} 2 p$ (Figs. S9 and S10), the concentration of the vacancies $(*)$ should be much lower than those of $\left(\mathrm{OH}^{*}\right)$ and $\left(\mathrm{O}^{*}\right)$ during the selective oxidation of toluene. Thus, a rate expression can be derived in the following form:

$$
r=\frac{k_{2} K_{1}\left[C_{7} H_{8}\right]}{\left\{1+\left(\frac{\left[H_{2} O\right]}{K_{4}}\right)^{0.5}\left(\frac{k_{2} K_{1}\left[C_{7} H_{8}\right]}{2 k_{5}\left[O_{2}\right]}\right)^{0.25}\right\}^{2}}
$$

where $K_{i}$ and $k_{i}$ are the equilibrium constant and rate coefficient, respectively, for reaction $i$. Under the condition of a low concentration of $\mathrm{H}_{2} \mathrm{O}$, the rate of the selective oxidation of toluene expressed by Eq. (6) can be further simplified to:

$$
r=k_{2} K_{1}\left[\mathrm{C}_{7} \mathrm{H}_{8}\right]=k\left[\mathrm{C}_{7} \mathrm{H}_{8}\right]
$$

where $k$ is equal to $k_{2} K_{1}$. The rate of the selective oxidation of toluene follows first and zero order for the toluene and $\mathrm{O}_{2}$ concentrations, respectively, with very low $\mathrm{H}_{2} \mathrm{O}$ concentration. This is in good agreement with the experimental results, indicating the rationality of the assumptions made in the elementary steps. The steps summarized are consistent with those shown in Fig. 1(b).

Based on the revealed mechanism, the better toluene conversion catalytic performance in a gas-liquid-solid reactor compared to a gas-solid fixed-bed reactor is understood. (1) Adequate amounts of acid in the liquid phase can decrease the stability of bidentate HDPA, promoting the redox cycle of the catalysts. (2) The existence of a liquid phase assists in the desorption of benzaldehyde (b.p. $179^{\circ} \mathrm{C}$ ) from the catalytic site. (3) The liquid phase assists in the movement of HDPA away from the catalyst surface, lowering the mass transfer resistance during the reaction. (4) The aqueous solution promotes the stability of HDPA during the oxidation reaction.

\section{Conclusions}

In summary, $\mathrm{HDPA}-\mathrm{FeMO}_{x} / \gamma-\mathrm{Al}_{2} \mathrm{O}_{3}$ is an enzyme-like catalyst specific for use in toluene reactions under mild conditions, which can convert toluene exclusively to benzaldehyde through $\mathrm{O}_{2}$ oxidation at $70{ }^{\circ} \mathrm{C}$. The active sites are related to monodentate HDPA bonded to the oxide surface. The other phosphorous hydroxyl cyclically converts between the states of unbonding and bonding during the reaction, corresponding to the oxidized and reduced catalyst states, respectively. Through the interchange between monodentate and bidentate HDPA, the mobil- 
ity of the crystal oxygen species or reactivity of the iron-based oxides is greatly enhanced for the toluene reaction. The newly revealed mechanism shows that the catalyst is much more efficient in gas-liquid-solid reaction conditions for the conversion of toluene to benzaldehyde. We envision that this novel mechanism for nanoparticle-derived and bioinspired catalysts is an attractive route for the design of high-performance catalysts for the selective oxidation of organic molecules.

\section{Notes}

The authors declare no competing financial interest.

\section{Electronic supporting information}

Supporting information is available in the online version of this article.

\section{References}

[1] National Research Council, Board on Chemical Sciences and Technology, Panel on New Directions in Catalytic Science and Technology, Catalysis Looks to the Future. National Academy Press, Washington, DC, 1992, pp. 23-24.

[2] L. Li, J. G. Lv, Y. Shen, X. F. Guo, L. M. Peng, Z. Xie, W. P. Ding, ACS Catal., 2014, 4, 2746-2752.

[3] J. G. Lv, Y. Shen, L. M. Peng, X. F. Guo, W. P. Ding, Chem. Commun., 2010, 46, 5909-5911.

[4] E. Gaster, S. Kozuch, D. Pappo, Angew. Chem. Int. Ed., 2017, 56, 5912-5915.

[5] Z. Liang, T. Li, M. Kim, A. Asthagiri, J. F. Weaver, Science, 2017, 356, 299-303.

[6] L. Kesavan, R. Tiruvalam, M. H. Ab Rahim, M. I. bin Saiman, D. I. Enache, R. L. Jenkins, N. Dimitratos, J. A. Lopez-Sanchez, S. H. Taylor, D. W. Knight, C. J. Kiely, G. J. Hutchings, Science, 2011, 331, 195-199.

[7] C. S. Deng, M. X. Xu, Z. Dong, L. Li, J. Y. Yang, X. F. Guo, L. M. Peng, N. H. Xue, Y. Zhu, W. P. Ding, Chin. J. Catal., 2020, 41, 314-349.

[8] M. Liu, S. Shi, L. Zhao, C. Chen, J. Gao, J. Xu, Chin. J. Catal., 2019, 40, 1488-1493.
[9] S. Ghosh, S. S. Acharyya, D. Tripathi, R. Bal, J. Mater. Chem. A, 2014, 2, 15726-15733.

[10] W. Partenheimer, Adv. Synth. Catal., 2006, 348, 559-568.

[11] M. I. bin Saiman, G. L. Brett, R. Tiruvalam, M. M. Forde, K. Sharples, A. Thetford, R. L. Jenkins, N. Dimitratos, J. A. Lopez-Sanchez, D. M. Murphy, D. Bethell, D. J. Willock, S. H. Taylor, D. W. Knight, C. J. Kiely, G. J. Hutchings, Angew. Chem. Int. Ed., 2012, 51, 5981-5985.

[12] N. Dimitratos, J. A. Lopez-Sanchez, G. J. Hutchings, Chem. Sci., 2012, $3,20-44$.

[13] M. Sankar, N. Dimitratos, P. J. Miedziak, P. P. Wells, C. J. Kiely, G. J. Hutchings, Chem. Soc. Rev., 2012, 41, 8099-8139.

[14] T. C. Bruice, F. C. Lightstone, Acc. Chem. Res., 1999, 32, 127-136.

[15] P. Zhang, D. R. Sun, A. Cho, S. Weon, S. Lee, J. Lee, J. W. Han, D.-P. Kim, W. Choi, Nat. Commun., 2019, 10, 940.

[16] M. D. Nothling, Z. Xiao, N. S. Hill, M. T. Blyth, A. Bhaskaran, M.-A. Sani, A. Espinosa-Gomez, K. Ngov, J. White, T. Buscher, F. Separovic, M. L. O’Mara, M. L. Coote, L. A. Connal, Sci. Adv., 2020, 6, eaaz0404.

[17] A. Warshel, P. K. Sharma, M. Kato, Y. Xiang, H. Liu, M. H. M. Olsson, Chem. Rev., 2006, 106, 3210-3235.

[18] E. Tabor, J. Dedecek, K. Mlekodaj, Z. Sobalik, P. C. Andrikopoulos, S. Sklenak, Sci. Adv., 2020, 6, eaaz9776.

[19] J. Baek, B. Rungtaweevoranit, X. K. Pei, M. Park, S. C. Fakra, Y.-S. Liu, R. Matheu, S. A. Alshmimri, S. Alshehri, C. A. Trickett, G. A. Somorjai, O. M. Yaghi, J. Am. Chem. Soc., 2018, 140, 18208-18216.

[20] S. A. Ikbal, C. Colomban, D. W. Zhang, M. Delecluse, T. Brotin, V. Dufaud, J.-P. Dutasta, A. B. Sorokin, A. Martinez, Inorg. Chem., 2019, 58, 7220-7228.

[21] B. J. Wallar, J. D. Lipscomb, Chem. Rev., 1996, 96, 2625-2657.

[22] M. Merkx, D. A. Kopp, M. H. Sazinsky, J. L. Blazyk, J. Müller, S. J. Lippard, Angew. Chem. Int. Ed., 2001, 40, 2782-2807.

[23] K. E. Liu, A. M. Valentine, D. L. Wang, B. H. Huynh, D. E. Edmondson, A. Salifoglou, S. J. Lippard, J. Am. Chem. Soc., 1995, 117, 10174-10185.

[24] S. K. Lee, J. C. Nesheim, J. D. Lipscomb, J. Biol. Chem., 1993, 268, 21569-21577.

[25] L. Que, Y. H. Dong, Acc. Chem. Res., 1996, 29, 190-196.

[26] C. E. Tinberg, S. J. Lippard, Acc. Chem. Res., 2011, 44, 280-288.

[27] W. M. Cai, S. E. Zhang, J. G. Lv, J. C. Chen, J. Yang, Y. B. Wang, X. F. Guo, L. M. Peng, W. P. Ding, Y. Chen, Y. Lei, Z. Chen, W. M. Yang, Z. Xie, ACS Catal., 2017, 7, 4083-4092.

[28] Y. Sahoo, H. Pizem, T. Fried, D. Golodnitsky, L. Burstein, C. N.

\section{Graphical Abstract}

Chin. J. Catal., 2021, 42: 1509-1518 doi: 10.1016/S1872-2067(20)63758-5

Enzyme-like mechanism of selective toluene oxidation to benzaldehyde over organophosphoric acid-bonded nano-oxides

Changshun Deng, Yun Cui, Junchao Chen, Teng Chen, Xuefeng Guo, Weijie Ji, Luming Peng, Weiping Ding * Nanjing University

HDPA-FeMO ${ }_{x} / \gamma-\mathrm{Al}_{2} \mathrm{O}_{3}$ is an enzyme-like catalyst for the exclusive conversion of toluene to benzaldehyde through $\mathrm{O}_{2}$ oxidation under mild conditions.

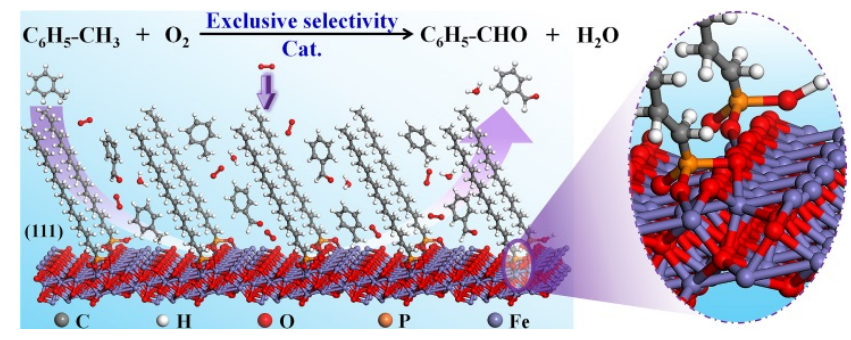


Sukenik, G. Markovich, Langmuir, 2001, 17, 7907-7911.

[29] J. Zhang, L. D. Ellis, B. W. Wang, M. J. Dzara, C. Sievers, S. Pylypenko, E. Nikolla, J. Will Medlin, Nat. Catal., 2018, 1, 148-155.

[30] C. Yee, G. Kataby, A. Ulman, T. Prozorov, H. White, A. King, M. Rafailovich, J. Sokolov, A. Gedanken, Langmuir, 1999, 15, 7111-7115.

[31] G. Busca, Phys. Chem. Chem. Phys., 1999, 1, 723-736.

[32] S. K. Davidowski, G. P. Holland, Langmuir, 2016, 32, 3253-3261.

[33] W. Gao, L. Dickinson, C. Grozinger, F. G. Morin, L. Reven, Langmuir, 1996, 12, 6429-6435.

[34] Z. B. Rui, M. N. Tang, W. K. Ji, J. J. Ding, H. B. Ji, Catal. Today, 2017, 297, 159-166.

[35] Z. R. Zhu, F. Y. Liu, W. Zhang, Mater. Res. Bull., 2015, 64, 68-75.

[36] W. M. Liao, P. P. Zhao, B. H. Cen, A. P. Jia, J. Q. Lu, M. F. Luo, Chin. J. Catal., 2020, 41, 442-453.

[37] S. Ramalingam, S. Periandy, M. Govindarajan, S. Mohan, Spectro- chim. Acta A, 2010, 75, 1308-1314.

[38] Z. P. Qu, Y. B. Bu, Y. Qin, Y. Wang, Q. Fu, Chem. Eng. J., 2012, 209, 163-169.

[39] J. P. H. Li, E. M. Kennedy, A. A. Adesina, M. Stockenhuber, J. Catal., 2019, 369, 157-167.

[40] Y. N. Liao, X. Zhang, R. S. Peng, M. Q. Zhao, D. Q. Ye, Appl. Surf. Sci., 2017, 405, 20-28.

[41] J. Palomar, J. L. G. De Paz, J. Catalán, Chem. Phys., 1999, 246, 167-208.

[42] W. J. Zhu, X. Chen, J. H. Jin, X. Di, C. H. Liang, Z. M. Liu, Chin. J. Catal., 2020, 41, 679-690.

[43] H. Sun, Z. G. Liu, S. Chen, X. Quan, Chem. Eng. J., 2015, 270, 58-65.

[44] M. W. Xue, J. Z. Ge, H. L. Zhang, J. Y. Shen, Appl. Catal. A: Gen., 2007, $330,117-126$.

[45] N. K. Nag, T. Fransen, P. Mars, J. Catal., 1981, 68, 77-85.

[46] E. Genty, S. Siffert, R. Cousin, Catal. Today, 2019, 333, 28-35.

\title{
烷基膦酸键合的纳米氧化物上甲苯选择氧化制苯甲醛的类酶机理
}

\author{
邓长顺, 崔 韵, 陈俊超, 陈 腾, 郭学锋, 季伟捷, 彭路明, 丁维平* \\ 南京大学化学化工学院, 介观化学教育部重点实验室,江苏南京 210023
}

摘要: 在传统催化反应中, 分子氧催化氧化烷烃生成目标产物的选择性最低, 常产生副产物以及大量的 $\mathrm{CO}_{x}$ 和水, 因需要复 杂的分离过程而导致流程的投资成本高. 因此, 在过去几十年里, 针对此类反应的研究以提高选择性为首要目标, 但克服 这一挑战的任务依然艰巨. 在此类反应中, 甲苯经 $\mathrm{O}_{2}$ 选择性催化氧化是制备苯甲醛的最佳途径, 但从未实现工业化, 其中 的主要难点在于苯甲醛在临氧条件下的继续氧化反应速率比甲苯氧化高 4 个数量级以上. 因此, 在高甲苯转化率下高选择 性获得苯甲醛是绿色化学研究中一个极具挑战性的课题.

本文发现一种甲苯/水的类皮克林乳液催化体系对甲苯转化为苯甲醛有很高的活性和选择性, 其中两性纳米颗粒(十六 烷基膦酸, 简写为HDPA, 键合的纳米铁基氧化物)作为催化剂并处在乳液相界面处. 在温和条件下通过 $\mathrm{O}_{2}$ 氧化, 苯甲酫的 时空产率大于 $2 \mathrm{~g}^{-} \mathrm{g}^{-1} \cdot \mathrm{h}^{-1}$, 整个过程没有使用 $\mathrm{H}_{2} \mathrm{O}_{2}$ 、卤素或其它自由基引发剂. 实验发现, 用于甲苯氧化反应的相关催化剂 $\mathrm{HDPA}-\mathrm{FeMO}_{x} / \gamma-\mathrm{Al}_{2} \mathrm{O}_{3}$ (M: V 和Mo等)的作用机制类似甲烷单加氧酶. 在传统固定床反应器中和温和的条件下 $\left(70 \sim 160^{\circ} \mathrm{C}\right.$, 常压), 催化剂能将甲苯单一氧化为苯甲酫. 催化剂的活性中心与HDPA以单齿态与氧化物表面键合有关, 并且它的另一个 磷羟基与氧化物表面在非键合态和键合态之间循环变化, 分别对应甲苯反应中催化剂的氧化态和还原态, 即HDPA与氧化 物表面通过单齿和双齿键合循环变化, 极大地提升了该铁基复合氧化物晶格氧的移动性而使得催化剂反应活性得到明显 提升.

透射电子显微镜、X射线衍射和氮吸附测量结果表明, 铁基复合金属氧化物在 $\gamma-\mathrm{Al}_{2} \mathrm{O}_{3}$ 纳米棒上具有良好的分散性和较 大的比表面积. X射线光电子能谱、吡啶吸附FT-IR 和 ${ }^{31}$ P NMR结果表明, 与表面键合的HDPA保留了有机膦酸属性, 没有与 $\mathrm{FeMO}_{x} / \gamma-\mathrm{Al}_{2} \mathrm{O}_{3}$ 生成体相磷酸盐, 其中, 以单齿状态与表面键合HDPA分子只占总数的 $2 \%$ 左右. $\mathrm{H}_{2}-\mathrm{TPR}$ 和CO-TPR结果表明, HDPA的键合强烈影响了晶格氧的流动性或金属氧化物的活性. 反应条件下原位FT-IR结果表明, HDPA- $\mathrm{FeVO}_{x} / \gamma-\mathrm{Al}_{2} \mathrm{O}_{3}$ 在 $70^{\circ} \mathrm{C}$ 下即能催化甲苯氧化成苯甲醛, 且不会过度氧化, 该催化剂的晶格氧物种可参与甲苯转化为苯甲醛. 此外, 发现 $\mathrm{HDPA}-\mathrm{Fe}_{2} \mathrm{O}_{3} / \gamma-\mathrm{Al}_{2} \mathrm{O}_{3}$ 对甲苯的吸附具有特殊的分子识别作用, 以苯甲醇氧化作为对照反应的研究结果也表明 $\mathrm{HDPA}-\mathrm{Fe}_{2} \mathrm{O}_{3} / \gamma-\mathrm{Al}_{2} \mathrm{O}_{3}$ 对甲苯氧化为苯甲醛的反应存特异催化作用. 宏观反应动力学测试结果表明, 催化剂上苯甲醛生成的 表观活化能仅为 $44.5 \mathrm{~kJ} / \mathrm{mol}$. 在低 $\mathrm{H}_{2} \mathrm{O}$ 浓度下, 甲苯氧化速率对甲苯浓度为一级反应, 对 $\mathrm{O}_{2}$ 浓度为零级反应, 基元反应步 骤推导出来的动力学方程与实验结果良好吻合, 说明了该催化剂上类酶反应基元步骤假设的合理性.

关键词: 选择氧化; 甲苯; 苯甲醛; 十六烷基膦酸; 类酶; 机理

收稿日期: 2020-11-19. 接受日期: 2021-01-11. 上网时间: 2021-05-05.

*通讯联系人.电话: (025)89685077; 传真: (025)89687761; 电子信箱: dingwp@nju.edu.cn 基金来源：国家自然科学基金(21932004, 91745108); 国家重点研发计划(2017YFB0702800).

本文的电子版全文由Elsevier出版社在ScienceDirect上出版(http://www.sciencedirect.com/journal/chinese-journal-of-catalysis). 